\title{
Nickel-Cerium Layered Double Hydroxide as Electrocatalyst for Glycerol Oxidation
}

\author{
Geovanne L. de Assis, ${ }^{\oplus *, a}$ Josué M. Gonçalves, ${ }^{a}$ Juliana S. Bernardes ${ }^{b}$ and Koiti Araki ${ }^{\oplus a}$ \\ ${ }^{a}$ Departamento de Química Fundamental, Instituto de Química, \\ Universidade de São Paulo, Av. Prof Lineu Prestes, 748, 05508-000 São Paulo-SP, Brazil \\ ${ }^{b}$ Laboratório Nacional de Nanotecnologia (LNNano), \\ Centro Nacional de Pesquisa em Energia e Materiais (CNPEM), \\ Rua Giuseppe Máximo Scolfaro, 10000, 13083-970 Campinas-SP, Brazil
}

\begin{abstract}
A new nickel based layered double hydroxide nanomaterial, $\mathrm{Ni}_{0.8} \mathrm{Ce}_{0.2}-\mathrm{LDH}$, constituted by about $3 \mathrm{~nm}$ large nanoparticles exhibiting enhanced electrocatalytic properties towards oxidation of glycerol in alkaline media, was prepared by incorporation of $20 \mathrm{wt} . \%$ of $\mathrm{Ce}^{\mathrm{III}}$ ions into $\alpha$-nickel hydroxide. This can be oxidized to $\mathrm{Ce}^{\mathrm{IV}}$, as demonstrated by $\mathrm{X}$-ray photoelectron spectroscopy, a much electron withdrawing and oxidizing species responsible for electronic interactions and additional electrocatalytic active sites giving rise to synergic effects. High-resolution transmission electron microscopy images and the X-ray diffractograms indicated a material with a significantly lower size and degree of crystallinity than $\alpha-\mathrm{Ni}(\mathrm{OH})_{2}$, one of the factors contributing to its enhanced electrochemical and electrocatalytic activity, as demonstrated by cyclic voltammetry and electrochemical impedance spectroscopy, suggesting a good potentiality for development of glycerol fuel cells.
\end{abstract}

Keywords: glycerol oxidation, nanostructured materials, NiCe-hydroxide, layered double hydroxides, $\alpha-\mathrm{Ni}(\mathrm{OH})_{2}$, electrocatalyst

\section{Introduction}

The increasing energy demand and the limited availability of fossil fuels are pushing the development of higher performance and environmentally friendly energy conversion and storage devices, which are one of the key technological challenges in the $21^{\text {st }}$ century. ${ }^{1}$ Fuels cells, electrochemical devices that convert chemical energy directly into electric energy, are promising alternatives to rechargeable batteries, ${ }^{2}$ especially when cheap byproducts such as glycerol is employed.

One type of fuel cell, a direct glycerol fuel cell (DGFC) using glycerol or glycerol solution as fuel and proton source is attractive because its storage is much simple and safe as compared with hydrogen gas. ${ }^{3}$ Moreover, glycerol is widely available from biodiesel production, being a resource produced in a renewable, more environmental-friendly, and cost effective manner. ${ }^{4}$ In addition, its electrooxidation in DGFCs cogenerate electricity and large amounts of high value chemicals ${ }^{5}$ as byproducts that can be utilized in the pharmaceutical, food, cosmetics and tobacco industries. ${ }^{6}$

*e-mail: geovannelemos@usp.br

Dedicated to Prof Henrique Eisi Toma on the occasion of his $70^{\text {th }}$ birthday.
In fact, many investigations have been conducted on glycerol oxidation exploring different types of electrode materials. ${ }^{7}$ Therefore, many research groups are focused on the development of electrocatalytic materials for this type of device. One class of such materials are the layered nanomaterials, that have attracted great attention due to the large interplanar distances that facilitate the intercalation of several compounds into the precursor materials, as well as their large surface areas ${ }^{8}$ and surface concentrations of active sites, favoring the diffusion of reactants and enhanced catalytic performance.

Among the layered transition metal oxides and hydroxides, $\mathrm{Ni}(\mathrm{OH})_{2}$ constitutes a class of electrocatalytic and electrochromic materials that have been extensively used in rechargeable batteries, ${ }^{9}$ hybrid supercapacitors, ${ }^{10}$ sensors ${ }^{11,12}$ and fuel cells. ${ }^{13}$ In fact, $\mathrm{Ni}(\mathrm{OH})_{2}$ nanoparticles (NPs) wrapped by poly[Ni(salen)] film (Ni(salen): $N, N^{\prime}$-bis(salicylidene)-ethylenediaminonickel(II) complex) was investigated as electrocatalyst for oxidation of methanol, ethanol and glycerol in alkaline electrolyte by Bott-Neto et al. ${ }^{7}$ The results show that the $\mathrm{Ni}^{\mathrm{II}}$-salen complex can be used as precursor of $\mathrm{Ni}(\mathrm{OH})_{2}$ based NP catalysts with average diameter of $2.4 \mathrm{~nm}$, uniformly dispersed in the polymeric matrix. In situ Fourier transform infrared (FTIR) 
spectroscopy studies confirmed that the electrocatalytic oxidation of those alcohols is dependent on the formation of the $\beta-\mathrm{NiOOH}$ species, and the oxidation products are similar to those produced in other nickel-based electrodes. In other words, $\beta-\mathrm{NiOOH}$ species is the electrocatalytic active species responsible for the oxidation of alcohols thus regenerating $\beta-\mathrm{Ni}(\mathrm{OH})_{2}$. However, it is important to highlight that the materials in the alpha phase $\left(\alpha-\mathrm{Ni}(\mathrm{OH})_{2}\right)$ exhibit a much more disorganized structure but higher electrocatalytic activity and specific charge capacity. ${ }^{14}$ Accordingly, the efficiency of alkaline fuel cells and energy storage devices tend to decrease as it is converted to crystalline $\beta-\mathrm{Ni}(\mathrm{OH})_{2}{ }^{15,16}$

Several studies have shown that the structural stability and electrochemical performance of modified $\alpha-\mathrm{Ni}(\mathrm{OH})_{2}$ are better than that of neat $\alpha-\mathrm{Ni}(\mathrm{OH})_{2} \cdot{ }^{17} \mathrm{In}$ fact, several studies have been carried out focusing on the isomorphic substitution of $\mathrm{Ni}^{\mathrm{II}}$ by others $\mathrm{M}^{\mathrm{II}}$ metal cations such as $\mathrm{Co}^{\mathrm{II}},{ }^{18} \mathrm{Mn}^{\mathrm{II}},{ }^{19}$ and $\mathrm{Zn}^{\mathrm{II}},{ }^{9}$ generating materials denominated double hydroxide salts (DHSs) and described by the general formula $\mathrm{M}_{1-\mathrm{x}}^{\mathrm{a}} \mathrm{M}_{\mathrm{x}}^{\mathrm{b}}(\mathrm{OH})_{2-\mathrm{x}}\left(\mathrm{A}^{\mathrm{m}-}\right)_{\mathrm{x} / \mathrm{m}} \cdot \mathrm{nH}_{2} \mathrm{O}$, where $\mathrm{M}^{\mathrm{a}}$ and $\mathrm{M}^{\mathrm{b}}$ are divalent metal cations. On the other hand, the incorporation of $\mathrm{M}^{\mathrm{III}}$ ions such as $\mathrm{Al}^{\mathrm{III}},{ }^{20,21} \mathrm{Co}^{\mathrm{III}},{ }^{22} \mathrm{Fe}^{\mathrm{III}}$, 23,24 and $\mathrm{Ce}^{\mathrm{III}},{ }^{25}$ results in the formation of layered double hydroxides (LDHs) represented by the general formula $\left[\mathrm{M} 1^{\mathrm{II}}{ }_{1-\mathrm{x}} \mathrm{M} 2^{\mathrm{III}}{ }_{\mathrm{x}}(\mathrm{OH})_{2}\right]_{\mathrm{x}}{ }^{+}\left(\mathrm{A}^{\mathrm{m}-}\right)_{\mathrm{x} / \mathrm{m}} \cdot \mathrm{nH}_{2} \mathrm{O}$, where $\mathrm{M} 1=\mathrm{Ni}^{\mathrm{II}}$ and $\mathrm{M} 2^{\mathrm{III}}$ are different metal cations in 3+ oxidation state, and $\mathrm{A}$ is the counter ion. ${ }^{26,27}$

In addition to increased stability, the DHSs and LDHs materials exhibit enhanced synergistic electrochemical properties. In this sense, $\mathrm{Ce}^{\mathrm{III}}$ based layered nanomaterials have also attracted much attention due to its high chemical stability, and excellent electric conductivity. ${ }^{28-30}$ In fact, Xu et al.,${ }^{31}$ developed Ce ${ }^{\mathrm{III}}$ doped NiFe-LDH/CNT (CNT: carbon nanotube) nanoarrays by in situ self-assembly at room temperature. The ternary NiFeCe-LDH/CNT electrocatalyst obtained in such a way displayed high OER (oxygen evolution reaction) activity and a substantially lower overpotential $\left(227 \mathrm{mV}\right.$ at $\left.10 \mathrm{~mA} \mathrm{~cm}^{-2}\right)$ and Tafel slope $\left(33 \mathrm{mV} \mathrm{dec}{ }^{-1}\right)$ in alkaline medium, competing favorably with NiFe-based LDHs, and outperforming commercial Ir/C catalysts. The OER activity of the nanocomposite was significantly enhanced mainly because of the much larger specific surface area, high density of lattice defects, much better electron transport efficiency, and synergetic effects associated with the redox properties and larger coordination number of $\mathrm{Ce}^{\mathrm{III}}$ incorporated in the layered nanostructure.

Accordingly, Ce-based LDHs are known to be excellent electrocatalytic materials because of its ability to store and transfer an oxygen atom concomitantly with an oxidation equivalent as expected for the reversible $\mathrm{Ce}^{\mathrm{IV}} / \mathrm{Ce}^{\mathrm{III}}$ process, its high oxygen carrying capacity and low price. ${ }^{32,33}$
In this context, hereon we describe the preparation, characterization and enhanced electrocatalytic properties of a new $\mathrm{Ni}_{0.8} \mathrm{Ce}_{0.2}$ - $\mathrm{LDH}$ and evidence for a possible direct participation of that rare earth ion in the glycerol electrooxidation reaction, in $1.0 \mathrm{~mol} \mathrm{~L}^{-1} \mathrm{NaOH}$.

\section{Experimental}

\section{Materials and methods}

Cerium(III) acetate $\left(\mathrm{Ce}\left(\mathrm{CH}_{3} \mathrm{COO}\right)_{3} \cdot \mathrm{xH}_{2} \mathrm{O}\right.$, purity $\geq 99.9 \%$, Sigma-Aldrich, Saint Louis, USA), nickel(II) acetate tetrahydrate $\left(\mathrm{Ni}\left(\mathrm{CH}_{3} \mathrm{COO}\right)_{2} \cdot 4 \mathrm{H}_{2} \mathrm{O}\right.$, purity $\geq 99.0 \%$, Sigma-Aldrich, Saint Louis, USA), n-butyl alcohol $\left(\mathrm{CH}_{3}\left(\mathrm{CH}_{2}\right)_{3} \mathrm{OH}\right.$, purity $\geq 99.5 \%$, Merck, Darmstadt, Germany), glycerol $\left(\mathrm{C}_{3} \mathrm{H}_{8} \mathrm{O}_{3}\right.$, purity $\geq 99.5 \%$, Synth, Diadema, Brazil), potassium hydroxide $(\mathrm{KOH}$, purity $\geq 86.1 \%$, Neon comercial, Suzano, Brazil), sodium hydroxide ( $\mathrm{NaOH}$, purity $\geq 97.9 \%$, Synth, Diadema, Brazil) and isopropyl alcohol $\left(\left(\mathrm{CH}_{3}\right)_{2} \mathrm{CHOH}\right.$, purity $\geq 99.5 \%$, Synth, Diadema, Brazil) were used as received, without further purification.

Preparation of $\alpha-\mathrm{Ni}(\mathrm{OH})_{2}$ and $\alpha-\mathrm{Ni}_{0.8} \mathrm{Ce}_{0.2}-\mathrm{LDH}$ nanoparticles

Sol suspensions of pure $\alpha-\mathrm{Ni}(\mathrm{OH})_{2}$ and Ce-incorporated $\alpha-\mathrm{Ni}(\mathrm{OH})_{2}\left(\alpha-\mathrm{Ni}_{1-\mathrm{x}} \mathrm{Ce}_{\mathrm{x}}-\mathrm{LDH}\right.$, where $\mathrm{x}=0.05,0.1$ and 0.2$)$ NPs were prepared in the stabilized $\alpha$ crystalline phase. The NiCe-LDH materials with increasing concentrations of $\mathrm{Ce}^{\mathrm{III}}$ ions exhibited similar structures and increasingly larger electrocatalytic activity but that become significantly larger only in $\mathrm{Ni}_{0.8} \mathrm{Ce}_{0.2}-\mathrm{LDH}$ as can be seen in the Figure $\mathrm{S} 1$ (Supplementary Information (SI) section), reason why now on this work will be focused on it. The $\alpha-\mathrm{Ni}(\mathrm{OH})_{2} \mathrm{NPs}$ were prepared by dissolving $4.82 \mathrm{mmol}$ of the nickel acetate in $25.0 \mathrm{~mL}$ of glycerol and adding stoichiometric amounts of $\mathrm{KOH}$ in $n$-butanol solution $(9.64 \mathrm{mmol}$ dissolved in $18.0 \mathrm{~mL}$ of $n$-butanol was added dropwise) at room temperature, according to a previously described procedure. ${ }^{34,35}$ The $\mathrm{Ni}_{0.8} \mathrm{Ce}_{0.2}-\mathrm{LDH}$ samples were prepared in a similar way by reacting a solution of nickel acetate $(3.86 \mathrm{mmol})$ and cerium acetate $(0.96 \mathrm{mmol})$ in $25.0 \mathrm{~mL}$ of glycerol with stoichiometric amounts of $\mathrm{KOH}$ in $n$-butanol solution (10.60 mmol in $18.0 \mathrm{~mL}$ of $n$-butanol). This solution was very quickly added into the former one at room temperature.

Preparation of $\alpha-\mathrm{Ni}(\mathrm{OH})_{2}$ and $\mathrm{Ni}_{0.8} \mathrm{Ce}_{0.2}-\mathrm{LDH}$ modified FTO electrodes

FTO (fluorine doped tin oxide) glass pieces $(1.0 \times 2.5 \mathrm{~cm})$ were carefully washed with soap and rinsed with isopropanol 
and water. Then, a $1 \mathrm{~cm}^{2}$ area was delimited on the surface with a scotch tape and $50 \mu \mathrm{L}$ of a nanomaterial suspension was spin-coated, the tape removed and the modified electrode heated at $240{ }^{\circ} \mathrm{C}$, for $30 \mathrm{~min}$, to produce adherent and mechanically stable films.

\section{Characterization}

The samples were characterized by X-ray diffractometry (XRD) in a Bruker D2 Phaser equipment (Germany) with a $\mathrm{Cu} \operatorname{K} \alpha$ source $\left(\lambda=1.5418 \AA, 30 \mathrm{kV}, 15 \mathrm{~mA}\right.$, step $\left.=0.05^{\circ}\right)$ and air-scatter screens to avoid diffuse scattering at lower angles, in the $2 \theta$ range from 5 to $70^{\circ}$. Samples were prepared on glass substrates by depositing $50 \mu \mathrm{L}$ of a nanoparticle suspension and heating at $240{ }^{\circ} \mathrm{C}$ for $30 \mathrm{~min}$.

Chemical surface analyses were carried out by X-ray photoelectron spectroscopy (XPS), using a K- $\alpha$ X-ray photoelectron spectrometer (Thermo Fisher Scientific, UK) equipped with a hemispherical electron analyzer and monochromatic $\mathrm{Al} \mathrm{K \alpha}(1486.6 \mathrm{eV})$ radiation source. Survey (full-range) and high-resolution spectra of $\mathrm{Ce}$ and $\mathrm{Ni}$ were acquired using pass energy of 200 and $50 \mathrm{eV}$, respectively, and the data analyses carried out using the Thermo Avantage Software (version 5.921). The XPS results presented in this work correspond to the average of at least three independent measurements performed in different regions of each sample.

Transmission electron microscopy (TEM) and highresolution transmission electron microscopy (HRTEM) images were obtained in a JEOL JSM-FEG 7401F equipment (Japan), at an accelerating voltage of $200 \mathrm{kV}$. Samples were prepared on copper grids (Ted Pella) by dispersing $3 \mu \mathrm{L}$ of a nanoparticle suspension diluted in deionized water.

\section{Electrochemical measurements}

All electrochemical measurements were conducted using a PGSTAT 30 electrochemical workstation (Autolab, Metrohm, Netherlands) and a classical three electrodes configuration cell at room temperature, and a $1.0 \mathrm{~mol} \mathrm{~L}^{-1}$ $\mathrm{NaOH}$ aqueous solution as electrolyte. FTO electrodes modified with $\alpha-\mathrm{Ni}(\mathrm{OH})_{2}$ and $\mathrm{Ni}_{0.8} \mathrm{Ce}_{0.2}-\mathrm{LDH}$ were employed as the working electrode (Figure S2, SI section), while a platinum foil and $\mathrm{Ag} / \mathrm{AgCl}\left(\mathrm{KCl}, 3.0 \mathrm{~mol} \mathrm{~L}^{-1}\right)$ were respectively used as the counter and reference electrodes.

The activity of the nanocatalysts for glycerol electrooxidation was measured by cyclic voltammetry in $1.0 \mathrm{~mol} \mathrm{~L}^{-1} \mathrm{NaOH}$ solution containing $1.9 \mathrm{mmol} \mathrm{L}^{-1}$ of glycerol, at room temperature. The $\mathrm{CV}$ curves were recorded in the potential range from 0.10 to $0.55 \mathrm{~V}$, at scan rate of $50 \mathrm{mV} \mathrm{s}^{-1}$.
The electrochemical impedance spectra were recorded at $0.5 \mathrm{~V}$ using the same electrochemical arrangement, modulating the frequency of the sinusoidal potential wave (amplitude $=10 \mathrm{mV}$ ) superimposed to the AC potential from $100 \mathrm{kHz}$ to $0.01 \mathrm{~Hz}$.

\section{Results and Discussion}

\section{Physicochemical characterization}

TEM images were used to estimate the $\alpha-\mathrm{Ni}(\mathrm{OH})_{2}$ and $\mathrm{Ni}_{0.8} \mathrm{Ce}_{0.2}$ - $\mathrm{LDH}$ nanoparticles size and morphology using samples prepared by depositing them on graphene oxide sheets, as shown in Figure 1. It is interesting to note that $\mathrm{Ni}_{0.8} \mathrm{Ce}_{0.2}$-LDH NPs are much smaller suggesting that $\mathrm{Ce}^{\mathrm{III}}$ ions probably are introducing a significant local distortion/stress to the lattice generating defective sites. A similar influence of cerium ions has also been observed by $\mathrm{Xu}$ et al. ${ }^{31}$ in the NiFeCe-LDH/CNT composite, in which $5 \mathrm{wt} . \%$ of $\mathrm{Ce}^{\mathrm{III}}$ ions was shown to be enough to reduce the average NPs size. It is worth noting here the possibility of $\mathrm{Ni}_{0.8} \mathrm{Ce}_{0.2}-\mathrm{LDH}$ conversion to $(\mathrm{NiCe}) \mathrm{O}_{\mathrm{x}}$ by the electron beam due to the local heating and the high vacuum in the sample chamber, generating oxide NPs. ${ }^{36}$

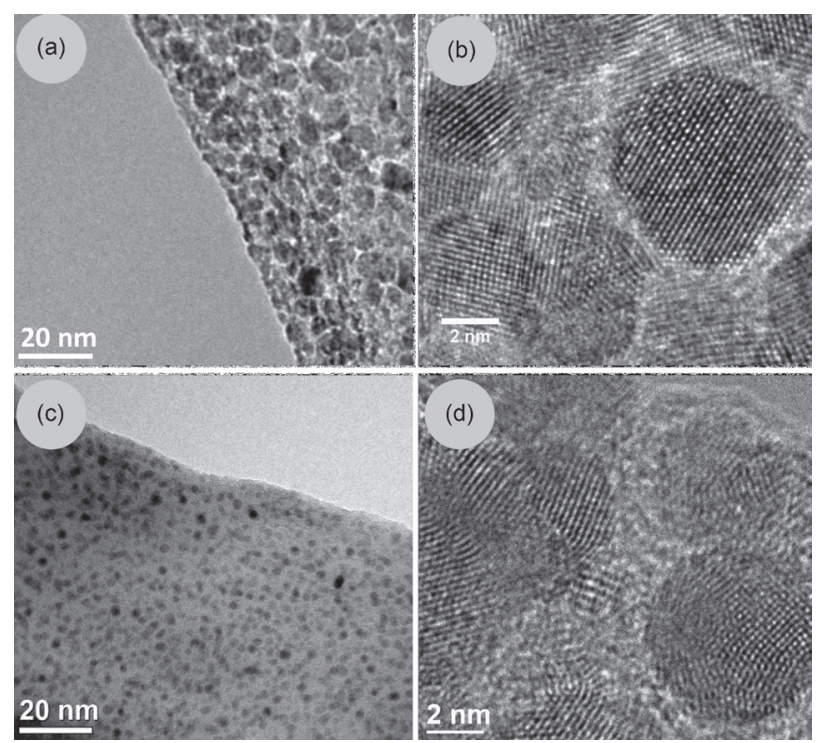

Figure 1. TEM and HRTEM images of (a, b) $\alpha-\mathrm{Ni}(\mathrm{OH})_{2}$ and (c, d) $\mathrm{Ni}_{0.8} \mathrm{Ce}_{0.2}-\mathrm{LDH}$.

In our work, 20 wt. $\%$ of $\mathrm{Ce}^{\mathrm{III}}$ ions in $\alpha-\mathrm{Ni}(\mathrm{OH})_{2}$ decreased the nanoparticle size from 6 to ca. $3 \mathrm{~nm}$. Such effect can be ascribed to the contrasting NPs nucleation rates and/or lattice distortion caused by the $\mathrm{Ce}^{\mathrm{III}}$ ions. In fact, a faster nucleation can favor the growth of smaller crystals, as previously demonstrated for incorporation of lanthanide ions..$^{37}$ In addition, the incorporation of much 
larger $\mathrm{Ce}^{\mathrm{III}}\left(102 \mathrm{pm}\right.$ as compared to $72 \mathrm{pm}$ of $\left.\mathrm{Ni}^{\mathrm{II}}\right)$ ions into $\mathrm{Ni}(\mathrm{OH})_{2}$ producing $\mathrm{Ni}_{0.8} \mathrm{Ce}_{0.2}-\mathrm{LDH}$ tend to generate local stress and lattice distortions that may hamper the growth of layered double hydroxide nanocrystals.

The structural information of $\mathrm{Ni}(\mathrm{OH})_{2}$ and $\mathrm{Ni}_{0.8} \mathrm{Ce}_{0.2}$-LDH NPs was obtained by XRD measurements, as shown in the diffractograms of the respective samples prepared by depositing the materials on glass substrates (Figure 2). The $\mathrm{Ni}(\mathrm{OH})_{2}$ sample presented a peak at $10.50^{\circ}$ which can be indexed to the (003) plane characteristic of the material in the $\alpha$-phase..$^{38}$ In fact, this is the most characteristic feature of the significantly more disordered $\alpha$-phase material, as compared to the crystalline $\beta$-phase material exhibiting several sharp peaks in the diffractogram. Similarly, considering an isomorphic substitution of $\mathrm{Ni}^{\mathrm{II}}$ by $\mathrm{Ce} \mathrm{e}^{\mathrm{III}}$ ions, the main diffraction peak of $\mathrm{Ni}_{0.8} \mathrm{Ce}_{0.2^{-}}$ $\mathrm{LDH}$ at $10.42^{\circ}$ was assigned to the respective layered double hydroxide material. The incorporation of $\mathrm{Ce}^{\mathrm{III}}$ ions $(102 \mathrm{pm})$, much larger than $\mathrm{Ni}^{\mathrm{II}}(72 \mathrm{pm})$, did not change significantly the interplanar distances, and the basal spacing of $\alpha-\mathrm{Ni}(\mathrm{OH})_{2}\left(\mathrm{~d}_{003}\right.$ ca. $\left.0.84 \mathrm{~nm}\right)$ was not significantly increased in $\mathrm{Ni}_{0.8} \mathrm{Ce}_{0.2}-\mathrm{LDH}\left(\mathrm{d}_{003}\right.$ ca. $\left.0.86 \mathrm{~nm}\right)$. Nevertheless, the clearly apparent lower intensity and broadness of that XRD peak is characteristic of a less crystalline material, and/or a material constituted by smaller size particles, as expected. The formation of $\mathrm{Ni}_{0.8} \mathrm{Ce}_{0.2^{-}}$ LDH nanoparticles was confirmed by STEM (scanning transmission electron microscopy), where the bright field image (Figure S4a, transmitted electrons, BF) and dark field (Figure S4b, scattered in high-angle annular dark field, HAADF) exhibited similar contrast and no clear indication of segregation of the $\mathrm{Ni}(\mathrm{OH})_{2}$ and $\mathrm{Ce}(\mathrm{OH})_{3}$ phases. ${ }^{25}$ These results indicates that $20 \mathrm{wt} . \%$ of $\mathrm{Ce}^{\mathrm{III}}$ ions was incorporated into the $\alpha-\mathrm{Ni}(\mathrm{OH})_{2}$ lattice without any

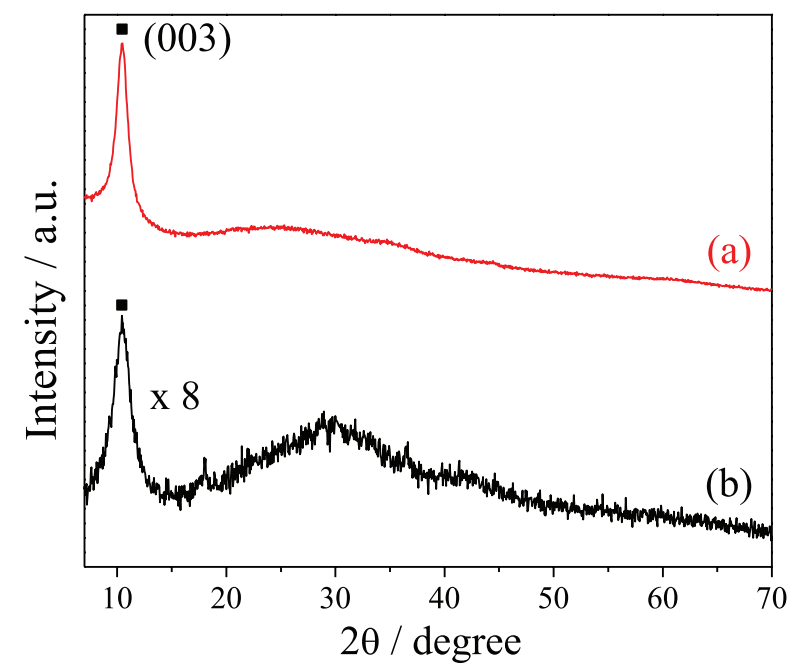

Figure 2. X-ray diffractograms of (a) $\alpha-\mathrm{Ni}(\mathrm{OH})_{2}$ and (b) $\mathrm{Ni}_{0.8} \mathrm{Ce}_{0.2}-\mathrm{LDH}$ nanoparticles deposited on a glass substrate. segregation or phase separation, generating a completely homogeneous material, demonstrating the suitability of the sol-gel method. In fact, this method is attracting considerable attention because employs mild conditions and allows good and easy control of the structure, composition and the degree of homogeneity. ${ }^{38}$

The eventual presence of nickel hydroxide derivative in the more organized $\beta$ phase was further evaluated by FTIR data as shown in SI section (Figure S5). The broad band at $650 \mathrm{~cm}^{-1}$ in the $\alpha-\mathrm{Ni}(\mathrm{OH})_{2}$ spectrum is characteristic of the $\delta(\mathrm{OH})$, but this same IR-active band appears at $500 \mathrm{~cm}^{-1}$ in $\beta-\mathrm{Ni}(\mathrm{OH})_{2},{ }^{39,40}$ confirming the presence of nickel hydroxide in the $\alpha$-phase. The incorporation of $\mathrm{Ce}^{\mathrm{III}}$ ions into $\alpha-\mathrm{Ni}(\mathrm{OH})_{2}$ decreased the intensity of that band and led to appearance of two sharper bands at 605 and $669 \mathrm{~cm}^{-1}$ probably associated with $\delta(\mathrm{OH})$ bond to cerium and nickel sites next to cerium ions as expected for the NiCe-LDH material. In addition, the two bands at 1558 and $1417 \mathrm{~cm}^{-1}$ has been assigned to $v_{\mathrm{a}}(\mathrm{OCO})$ and $v_{\mathrm{s}}(\mathrm{OCO})$ stretching vibrations of organic acid anions, respectively, ${ }^{41}$ and that at $1383 \mathrm{~cm}^{-1}$ must be assigned to $\delta(\mathrm{CH})$ or $\rho_{\mathrm{r}}(\mathrm{COO})$ stretching/bending vibrations of $\mathrm{CH}$ and carboxylate groups, ${ }^{7}$ respectively. These carboxylatecontaining species were probably produced during the heat treatment of the samples $\left(\alpha-\mathrm{Ni}(\mathrm{OH})_{2}\right.$ and NiCe-LDH films) by oxidative breakdown of glycerol molecules, which were used as solvent during the synthetic procedure, thus generating smaller compounds such as carbonate and oxalate. As reported by Rives, ${ }^{42}$ the presence of intercalated carbonate and oxalate anions in these class of compounds induce interlayer spacing about $0.80 \mathrm{~nm}$ for carbonate and in the range of 0.80-0.90 $\mathrm{nm}$ for oxalate anions, which are in accordance with the present work $(0.84$ and $0.86 \mathrm{~nm})$. However, the presence of interlayered acetate anions (from precursor salts) coordinated perpendicularly to the plane of the layer has been ruled out, since which would increase the interlamellar spacing to ca. $1.30 \mathrm{~nm}$ as described by Choy et al..$^{43}$

XPS measurements were carried out for determination of the valence states of $\mathrm{Ni}$ and $\mathrm{Ce}$ in the nanomaterial. The Ni $2 p$ region of $\alpha-\mathrm{Ni}(\mathrm{OH})_{2}$ and $\mathrm{Ni}_{0.8} \mathrm{Ce}_{0.2}-\mathrm{LDH}$ (Figure 3a) shows the typical $\mathrm{Ni}^{\mathrm{II}}$ peaks respectively at $873.7 \mathrm{eV}\left(\mathrm{Ni} 2 \mathrm{p}_{1 / 2}\right)$ and $855.9 \mathrm{eV}\left(\mathrm{Ni} 2 \mathrm{p}_{3 / 2}\right)$, and $873.3 \mathrm{eV}$ $\left(\mathrm{Ni} 2 \mathrm{p}_{1 / 2}\right)$ and $855.7 \mathrm{eV}\left(\mathrm{Ni} 2 \mathrm{p}_{3 / 2}\right)$, with their corresponding satellites, in good agreement with the spectrum of a standard $\alpha-\mathrm{Ni}(\mathrm{OH})_{2}$ sample exhibiting peaks at $873.3 \mathrm{eV}$ $\left(\mathrm{Ni} 2 \mathrm{p}_{1 / 2}\right)$ and $855.6 \mathrm{eV}\left(\mathrm{Ni} 2 \mathrm{p}_{3 / 2}\right)$. The $\mathrm{Ce} 3 \mathrm{~d}$ high resolution spectrum (Figure $3 b$ ) exhibits the $\mathrm{Ce} 3 \mathrm{~d}_{3 / 2}$ and $\mathrm{Ce} 3 \mathrm{~d}_{5 / 2}$ peaks respectively at 904.0 and $885.3 \mathrm{eV},{ }^{31}$ confirming the presence of $\mathrm{Ce}^{\mathrm{III}}$ in $\mathrm{Ni}_{0.8} \mathrm{Ce}_{0.2}$ - $\mathrm{LDH}$. However, there is a positive shift of $1.3 \mathrm{eV}$ as compared to that of $\mathrm{Ce}(\mathrm{OH})_{3}$ 
reference, indicating a significantly lower electron binding energy for the $\mathrm{Ce}^{\mathrm{III}}$ ions as expected for the presence of less electronegative $\mathrm{Ni}^{\mathrm{II}}$ ions bond next to them. Also, it is interesting to note that a weak peak characteristic of $\mathrm{CeO}_{2}$ like sites appeared at $917 \mathrm{eV}$ after heat treatment at $240{ }^{\circ} \mathrm{C}$ for $30 \mathrm{~min}$ (Figure 3c) indicating that site is available for redox processes. This is a very interesting feature since $\mathrm{Ce}^{\mathrm{IV}}$ is an potent oxidizing species that besides creating new catalytic active sites may induce synergic effects enhancing the electrocatalytic activity of the NiCe-LDH material for oxidation reactions, as compared to pure $\alpha-\mathrm{Ni}(\mathrm{OH})_{2}$.

\section{Electrochemical properties}

The electrochemical performance of $\alpha-\mathrm{Ni}(\mathrm{OH})_{2}$ and $\mathrm{Ni}_{0.8} \mathrm{Ce}_{0.2}$-LDH NPs modified FTO electrodes were evaluated by cyclic voltammetry $(\mathrm{CV})$ measurements within a potential window from 0.10 to $0.55 \mathrm{~V}$ (vs. $\mathrm{Ag} / \mathrm{AgCl} 3.0 \mathrm{~mol} \mathrm{~L}^{-1}$ ) in aqueous $1.0 \mathrm{~mol} \mathrm{~L}^{-1} \mathrm{NaOH}$ solution. The electrochemical behavior during $100 \mathrm{CV}$ cycles at $50 \mathrm{mV} \mathrm{s}^{-1}$ is shown in Figure 4. Note that both materials present an increase in the current as a function of the number of $\mathrm{CV}$ cycles. This behavior was attributed to the progressive diffusion of the electrolyte solution into the nanomaterial activating more and more $\mathrm{Ni}^{\mathrm{II}}$ sites, as previously reported. ${ }^{44}$ The oxidation peak was found at $0.43 \mathrm{~V}(v s . \mathrm{Hg} / \mathrm{HgO}, \mathrm{KOH} 1 \mathrm{M})$, a potentially typically assigned to the $\alpha$-nickel hydroxide materials, while that peak appears shifted to potentials more positive than about $0.5 \mathrm{~V}$ (vs. $\mathrm{Hg} / \mathrm{HgO}, \mathrm{KOH} 1 \mathrm{M}$ ) in the $\beta$ phase material. ${ }^{45}$
It is easy to see that the $\mathrm{Ni}_{0.8} \mathrm{Ce}_{0.2}$ - $\mathrm{LDH} / \mathrm{FTO}$ electrode exhibits much broad waves than the $\alpha-\mathrm{Ni}(\mathrm{OH})_{2} / \mathrm{FTO}$ electrode but with similar peak currents, indicating that the amount of exchanged electrons is much larger, or in other words, that the concentration of redox active sites is much larger. This is a very important feature of an electrocatalyst and the wave broadening suggests that the activated $\mathrm{Ni}^{\mathrm{II}}$ sites probably are in different chemical environments in the LDH lattice. Such a broadening can also be consequence of the resistance to electrolyte diffusion as observed when the thickness of the film deposited on FTO was increased, as previously reported, ${ }^{25}$ but this is not the case here. The anodic peak at around $0.35 \mathrm{~V}$ is attributed to the oxidation of $\alpha-\mathrm{Ni}(\mathrm{OH})_{2}$ to $\gamma-\mathrm{NiOOH}$, while the cathodic peak at $0.26 \mathrm{~V}$ is related to the reverse reaction, according to the following electrochemical process: ${ }^{46,47}$

$\alpha-\mathrm{Ni}(\mathrm{OH})_{2}+\mathrm{OH}^{-} \rightarrow \gamma-\mathrm{NiOOH}+\mathrm{H}_{2} \mathrm{O}+\mathrm{e}^{-}$

The electrocatalytic activity of $\alpha-\mathrm{Ni}(\mathrm{OH})_{2}$ and $\mathrm{Ni}_{0.8} \mathrm{Ce}_{0.2}$ - $\mathrm{LDH}$ modified FTO electrodes for oxidation of glycerol was investigated by cyclic voltammetry in $1.0 \mathrm{~mol} \mathrm{~L}^{-1} \mathrm{NaOH}$ solution (Figures 5a and 5c) since LDH derivatives prepared with lower $\mathrm{Ce}^{\mathrm{III}}$ content did not exhibit significantly larger electrocatalytic activity as compared to pure $\alpha$-nickel hydroxide (Figure S1, SI section). The CV curves in the presence of $1.9 \mathrm{mmol} \mathrm{L}^{-1}$ of glycerol clearly demonstrates the much larger electrocatalytic activity of the LDH material, which presented 1.7 times larger current at $0.50 \mathrm{~V}$.
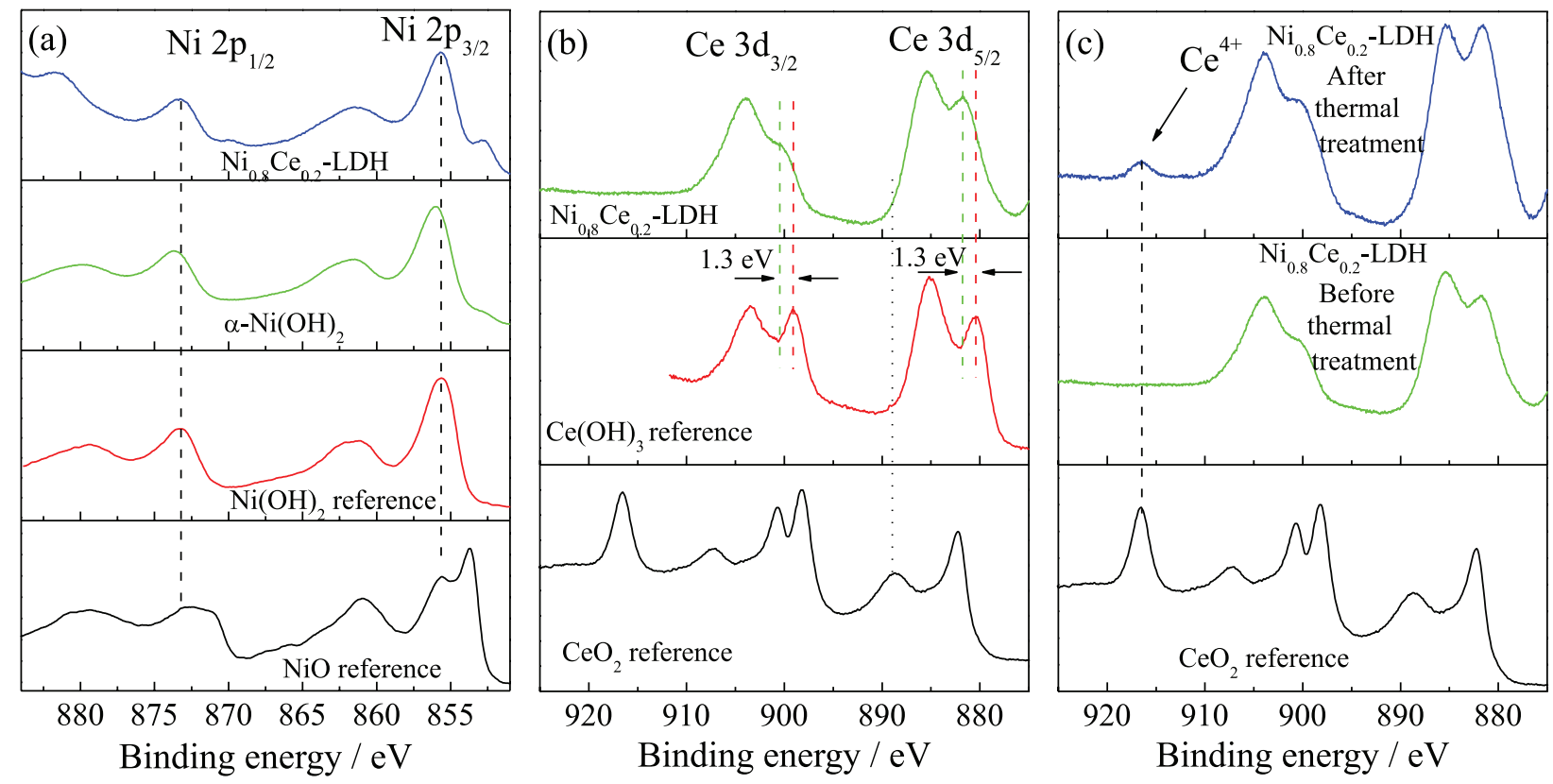

Figure 3. High resolution XPS spectra of $\alpha-\mathrm{Ni}(\mathrm{OH})_{2}$ and $\mathrm{Ni}_{0.8} \mathrm{Ce}_{0.2}-\mathrm{LDH}$ in the (a) $\mathrm{Ni} 2 \mathrm{p}$ region, and (b) Ce $3 \mathrm{~d}$ region, and (c) of $\mathrm{Ni}_{0.8} \mathrm{Ce}_{0.2}-\mathrm{LDH}$ before and after calcination at $240{ }^{\circ} \mathrm{C}$ for $30 \mathrm{~min}$. 

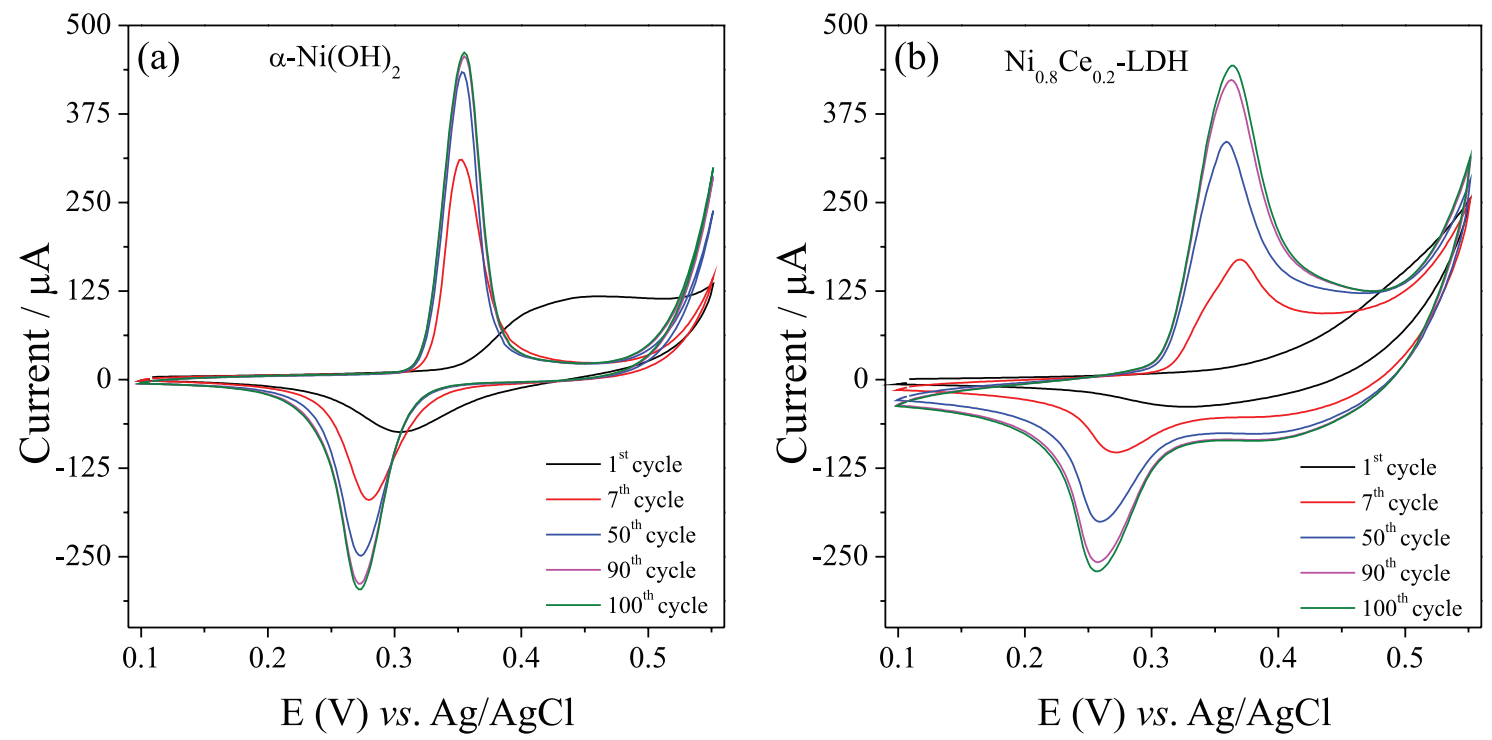

Figure 4. Cyclic voltammograms of (a) $\alpha-\mathrm{Ni}(\mathrm{OH})_{2}$ and (b) $\mathrm{Ni}_{0.8} \mathrm{Ce}_{0.2}-\mathrm{LDH}$ modified $\mathrm{FTO}$ electrodes as a function of the number of cycles in 1.0 mol $\mathrm{L}^{-1}$ $\mathrm{NaOH}$ solution, at $50 \mathrm{mV} \mathrm{s}^{-1}$.

Accordingly, electrochemical impedance spectroscopy (EIS) measurements were performed to clarify the electrochemical properties at $0.50 \mathrm{~V}$, using an amplitude AC perturbation of $10 \mathrm{mV}$, in the $0.01 \mathrm{~Hz}$ to $100 \mathrm{kHz}$ range, and the respective Nyquist plots are shown in Figures $5 b$ and $5 \mathrm{~d}$. The equivalent circuit used to fit the experimental data is shown in the inset of Figure $5 d$, in which $R_{s}$ represents the combined resistance of the electrolyte, the intrinsic resistance of FTO, and the contact resistance of the nanomaterials with the FTO substrate; $\mathrm{R}_{1}$ represents the charge-diffusion resistance in the modified electrodes, and $R_{2}$ the heterogeneous charge-transfer resistance for oxidation of glycerol (or water) on the electrode surface. The impedance parameters obtained by fitting the experimental data are listed in Table 1.

The $R_{1}$ values are relatively low as expected spanning the 7.1 to $12.0 \mathrm{ohms}$ range, whilst $\mathrm{R}_{2}$ was significantly different for $\alpha-\mathrm{Ni}(\mathrm{OH})_{2}$ and $\mathrm{Ni}_{0.8} \mathrm{Ce}_{0.2}-\mathrm{LDH}$, in the absence and presence of glycerol. In fact, the heterogeneous charge-transfer resistance decreased from about $367 \mathrm{ohms}$ in the pure nickel hydroxide to $230 \mathrm{ohms}$ in the LDH material, as expected for its higher electrocatalytic activity. In addition, it is relevant to mention the quite significant decrease of such parameter, from 230 to $185 \mathrm{ohms}$ for LDH (and from 367 to $344 \mathrm{ohms}$ for $\alpha-\mathrm{Ni}(\mathrm{OH})_{2}$ ) upon addition of glycerol, indicating that this compound is more easily oxidized than water. ${ }^{48,49}$ Such an improvement in performance suggests that the presence of $\mathrm{Ce}^{\mathrm{III}}$ ions in the $\mathrm{LDH}$ material is beneficial and is increasing the heterogeneous charge-transfer kinetics. The possibility of improvement of the materials conductivity can be ruled out since no significant change of $R_{1}$ was observed upon incorporation of $20 \mathrm{wt} . \%$ of $\mathrm{Ce}^{\mathrm{III}}$ in the $\alpha-\mathrm{Ni}(\mathrm{OH})_{2}$ matrix (Table 1$)$.

As pointed out previously, $\mathrm{Ce}^{\mathrm{III}}$ ion is much larger than the $\mathrm{Ni}^{\mathrm{II}}$ ion and can induce local structural distortions that can enhance the activity of the nickel sites. However, we demonstrated by XPS that the $\mathrm{Ce}^{\mathrm{III}}$ ions can also be oxidized to $\mathrm{Ce}^{\mathrm{IV}}$ ions in the $\mathrm{NiOOH}$ structure, a species that is wellknown for its oxidizing properties. Accordingly, the glycerol electrooxidation mechanism may include the simultaneous action of both, the nickel and cerium sites. First, both sites are activated by oxidation to their respective higher valence states, then the electrochemically generated $\mathrm{Ni}^{\mathrm{III}}$ and $\mathrm{Ce}^{\mathrm{IV}}$ species oxidize glycerol and are reduced back regenerating the starting species, according to equations 2-5. Thus, the enhanced electrocatalytic activity was attributed to lattice distortions and the presence of catalytic active $\mathrm{Ce}^{\mathrm{IV}}$ sites, that can act in parallel or synergistic way. This last hypothesis is considered more probable given its very high electron withdrawing and electronegativity that also can activate further the electrocatalytic activity of the nickel sites for oxidation reactions.

$$
\begin{aligned}
& \mathrm{Ni}(\mathrm{OH})_{2}+\mathrm{OH}^{-} \rightarrow \mathrm{NiOOH}+\mathrm{H}_{2} \mathrm{O}+\mathrm{e}^{-} \\
& \mathrm{NiOOH}+\mathrm{Glycerol}^{-} \text {products }+\mathrm{Ni}(\mathrm{OH})_{2} \\
& \mathrm{Ce}(\mathrm{OH})_{3}+\mathrm{OH}^{-} \rightarrow \mathrm{CeO}_{2}+2 \mathrm{H}_{2} \mathrm{O}+\mathrm{e}^{-} \\
& \mathrm{CeO}_{2}+\text { Glycerol } \rightarrow \text { products }+\mathrm{Ce}(\mathrm{OH})_{3}
\end{aligned}
$$

To better evaluate the electrocatalytic activity of $\alpha-\mathrm{Ni}(\mathrm{OH})_{2}$ and $\mathrm{NiCe}-\mathrm{LDH}$ electrodes toward glycerol oxidation, the results obtained in this work were compared with related works in the literature. ${ }^{6,750,51}$ As shown in Table 2, the lowest oxidation potential of $0.50 \mathrm{~V}$, that 

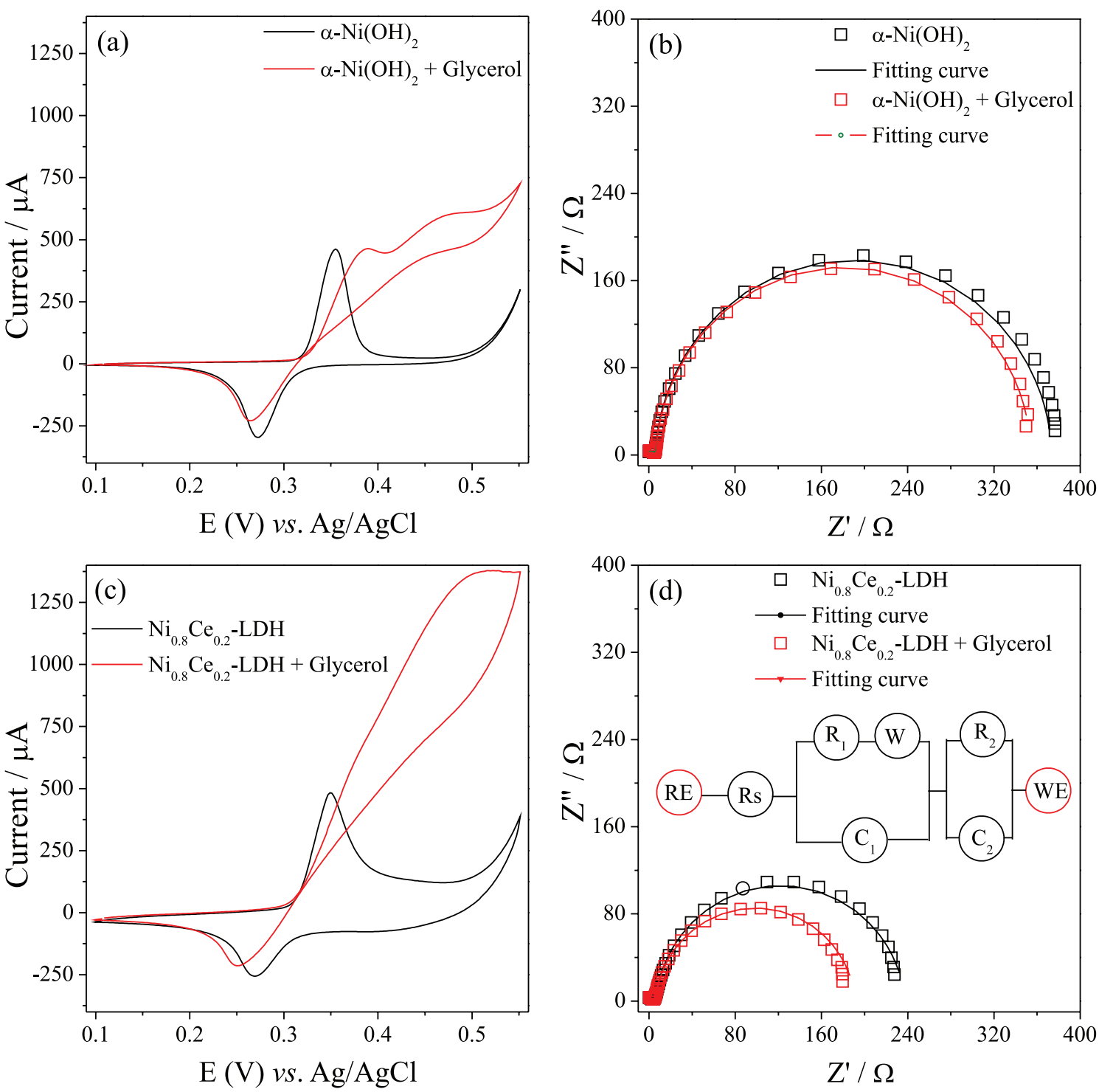

Figure 5. Cyclic voltammograms of (a) $\alpha-\mathrm{Ni}(\mathrm{OH})_{2}$ and (c) $\mathrm{Ni}_{0.8} \mathrm{Ce}_{0.2}-\mathrm{LDH}$ modified FTO electrodes in the absence and presence of $1.9 \mathrm{mmol} \mathrm{\textrm {L } ^ { - 1 }}$ of glycerol in $1.0 \mathrm{~mol} \mathrm{~L}^{-1} \mathrm{NaOH}$ electrolyte solution, at $50 \mathrm{mV} \mathrm{s}^{-1}$. Electrochemical impedance spectra recorded at $0.50 \mathrm{~V}$, in the frequency range from $0.01 \mathrm{~Hz}$ to $100 \mathrm{kHz}$ to of (b) $\alpha-\mathrm{Ni}(\mathrm{OH})_{2}$ and (d) $\mathrm{Ni}_{0.8} \mathrm{Ce}_{0.2}-\mathrm{LDH}$, and the equivalent circuit used for fitting (inset).

Table 1. EIS data of $\alpha-\mathrm{Ni}(\mathrm{OH})_{2}$ and $\mathrm{Ni}_{0.8} \mathrm{Ce}_{0.2}-\mathrm{LDH}$ in the absence and presence of glycerol $1.9 \mathrm{mmol} \mathrm{L}^{-1}$, at AC potential of $0.50 \mathrm{~V}$. Data obtained by fitting of Figures $5 \mathrm{~b}$ and $5 \mathrm{~d}$ data

\begin{tabular}{lccc}
\hline Material & $\mathrm{R}_{\mathrm{s}} / \Omega$ & $\mathrm{R}_{1} / \Omega$ & $\mathrm{R}_{2} / \Omega$ \\
\hline$\alpha-\mathrm{Ni}(\mathrm{OH})_{2}$ & 12.3 & 7.1 & 367.0 \\
$\alpha-\mathrm{Ni}(\mathrm{OH})_{2}+$ glycerol & 34.0 & 10.3 & 344.0 \\
$\mathrm{Ni}_{0.8} \mathrm{Ce}_{0.2}-\mathrm{LDH}$ & 10.5 & 10.0 & 230.0 \\
$\mathrm{Ni}_{0.8} \mathrm{Ce}_{0.2}-\mathrm{LDH}+$ glycerol & 17.0 & 12.0 & 185.0 \\
\hline
\end{tabular}

$\mathrm{R}_{\mathrm{s}}$ : combined resistance of the electrolyte, the intrinsic resistance of FTO, and the contact resistance of the nanomaterials with the FTO substrate; $\mathrm{R}_{1}$ : charge-diffusion resistance in the modified electrodes, $\mathrm{R}_{2}$ : heterogeneous charge-transfer resistance for oxidation of glycerol (or water) on the electrode surface; LDH: layered double hydroxides. indicates a larger electrocatalytic activity, was achieved with the nanomaterials described in this work. The other important parameter is the current density, but this parameter is highly dependent on the substrate concentration and the actual electrode surface area available for the electrocatalytic process and are not directly comparable. In our case, a thin film with relatively low surface area and a $1.9 \mathrm{mM}$ glycerol solution has been considered, while electrodes modified with thicker films with much larger active surface areas and $100 \mathrm{mM}$ glycerol solution was used in the other works. For example, a [Ni(salen)] derivative was electropolymerized on glassy carbon electrode surface generating a thick poly[Ni(salen) $]_{\text {ATV }}$ film exhibiting the highest current density of $31.4 \mathrm{~mA} \mathrm{~cm}^{-2}$. Accordingly, just considering that the substrate concentration is 50 times 
Table 2. Electrocatalytic activity of $\alpha-\mathrm{Ni}(\mathrm{OH})_{2} / \mathrm{FTO}$ and $\mathrm{NiCe}-\mathrm{LDH} / \mathrm{FTO}$ electrodes as compared to related modified electrodes for glycerol electrooxidation reaction

\begin{tabular}{|c|c|c|c|c|}
\hline Catalyst & Glycerol solution / $\mathrm{mM}$ & $\mathrm{E}_{\mathrm{pa}} / \mathrm{V}$ & $\mathrm{j} /\left(\mathrm{mA} \mathrm{cm}{ }^{-2}\right)$ & Reference \\
\hline$\alpha-\mathrm{Ni}(\mathrm{OH})_{2}$ & $1.9(1.0 \mathrm{M} \mathrm{NaOH})$ & 0.50 (vs. $\mathrm{Ag} / \mathrm{AgCl})$ & 1.1 & this work \\
\hline $\mathrm{NiCe}-\mathrm{LDH}$ & $1.9(1.0 \mathrm{M} \mathrm{NaOH})$ & 0.50 (vs. $\mathrm{Ag} / \mathrm{AgCl})$ & 2.6 & this work \\
\hline Untreated $\mathrm{Ni}$ & $100.0(1.0 \mathrm{M} \mathrm{KOH})$ & 0.60 (vs. $\mathrm{Hg} / \mathrm{HgO})$ & 4.5 & 6 \\
\hline After treatment $\mathrm{Ni}$ & $100.0(1.0 \mathrm{M} \mathrm{KOH})$ & 0.60 (vs. $\mathrm{Hg} / \mathrm{HgO})$ & 15.5 & 6 \\
\hline Poly $[\mathrm{Ni}(\text { salen })]_{\mathrm{ATV}}$ & $100.0(1.0 \mathrm{M} \mathrm{NaOH})$ & 0.59 (vs. $\mathrm{Ag} / \mathrm{AgCl})$ & 31.4 & 7 \\
\hline $\mathrm{Ni}-\mathrm{CA}$ & $100.0(1.0 \mathrm{M} \mathrm{KOH})$ & 0.55 (vs. $\mathrm{Ag} / \mathrm{AgCl})$ & 10.0 & 50 \\
\hline $\mathrm{Ni}-\mathrm{TBr}$ & $100.0(1.0 \mathrm{M} \mathrm{KOH})$ & 0.55 (vs. $\mathrm{Ag} / \mathrm{AgCl})$ & 8.5 & 50 \\
\hline $\mathrm{Ni}$ & $100.0(1.0 \mathrm{M} \mathrm{KOH})$ & 0.55 (vs. $\mathrm{Ag} / \mathrm{AgCl})$ & 4.5 & 50 \\
\hline$* \mathrm{Ni}$ & $100.0(0.5 \mathrm{M} \mathrm{NaOH})$ & 0.70 (vs. $\mathrm{Ag} / \mathrm{AgCl})$ & 20.0 & 51 \\
\hline
\end{tabular}

$\mathrm{E}_{\mathrm{pa}}$ : anodic peak potential; $\mathrm{j}$ : current density; $\mathrm{LDH}$ : layered double hydroxides; untreated Ni: untreated nickel wire; after treatment Ni: nickel wire treated in a solution of $\mathrm{Na}_{2} \mathrm{SO}_{4} /$ ascorbic acid; poly[Ni(salen)] $]_{\text {ATv }}: N, N$ '-bis(salicylidene)-ethylenediaminonickel(II) complex on glassy carbon disk; Ni-CA: nickel electrode-citric acid; Ni-TBr: nickel electrode-tetrabutylammonium bromide; Ni: nickel electrode; *Ni: polycrystalline nickel rod.

larger, the expected current density for NiCe-LDH modified electrodes in the same experimental conditions should be larger than $100 \mathrm{~mA} \mathrm{~cm}{ }^{-2}$, demonstrating its superior electrocatalytic activity.

\section{Conclusions}

The incorporation of $\mathrm{Ce}^{\mathrm{III}}$ ions into $\alpha-\mathrm{Ni}(\mathrm{OH})_{2}$ lattice influenced the nanoparticles size, degree of crystallinity and electrocatalytic activity of $\mathrm{Ni}_{0.8} \mathrm{Ce}_{0.2}-\mathrm{LDH}$, as demonstrated by TEM, XRD and electrochemical (CV and EIS) measurements. The larger $\mathrm{Ce}^{\mathrm{III}}$ ions probably are distorting the nickel hydroxide lattice and was shown to be easily oxidized generating $\mathrm{Ce}^{\mathrm{IV}}$ ion, a highly oxidizing and electron-withdrawing species that can act as additional electrocatalytic active site and induce synergic effects enhancing the electrocatalytic activity of the LDH material for oxidation of organic substrates. In fact, the layered double hydroxide material showed an enhanced electrocatalytic activity 1.7 times larger than $\alpha-\mathrm{Ni}(\mathrm{OH})_{2}$ for oxidation of glycerol, being promising for application in glycerol-based fuel cells.

\section{Supplementary Information}

Supplementary data (cyclic voltammetry, electrochemical impedance, ICP-OES (inductively coupled plasma optical emission spectrometry) and FTIR) are available free of charge at http://jbcs.sbq.org.br as PDF file.

\section{Acknowledgments}

The authors are grateful to the Brazilian agency Conselho Nacional de Desenvolvimento Científico e Tecnológico-CNPq (processes 131857/2016-9 and $141853 / 2015-8$ ) for financial support. We also thank Brazilian Nanotechnology National Laboratory-LNNano, CNPEM (Brazil) for the use of TEM and XPS facilities.

\section{References}

1. Pawar, S. M.; Inamdar, A. I.; Gurav, K. V.; Jo, Y.; Kim, H.; Kim, J. H.; Im, H.; Mater. Lett. 2015, 141, 336.

2. Spinacé, E. V.; Neto, A. O.; Vasconcelos, T. R. R.; Linardi, M.; J. Power Sources 2004, 137, 17.

3. Oliveira, V. L.; Morais, C.; Servat, K.; Napporn, T. W.; Tremiliosi-Filho, G.; Kokoh, K. B.; J. Electroanal. Chem. 2013, $703,56$.

4. Habibi, B.; Delnavaz, N.; RSC Adv. 2016, 6, 31797.

5. Coutanceau, C.; Baranton, S.; Kouamé, R. S. B.; Front. Chem. 2019, 7, 100.

6. Houache, M. S. E.; Cossar, E.; Ntais, S.; Baranova, E. A.; J. Power Sources 2018, 375, 310.

7. Bott-Neto, J. L.; Martins, T. S.; Machado, S. A. S.; Ticianelli, E. A.; ACS Appl. Mater. Interfaces 2019, 11, 30810.

8. Zha, D.; Sun, H.; Fu, Y.; Ouyang, X.; Wang, X.; Electrochim. Acta 2017, 236, 18.

9. Turney, D. E.; Shmukler, M.; Galloway, K.; Klein, M.; Ito, Y.; Sholklapper, T.; Gallaway, J. W.; Nyce, M.; Banerjee, S.; J. Power Sources 2014, 264, 49.

10. Guo, X. L.; Liu, X. Y.; Hao, X. D.; Zhu, S. J.; Dong, F.; Wen, Z. Q.; Zhang, Y. X.; Electrochim. Acta 2016, 194, 179.

11. Rinaldi, A. L.; Carballo, R.; Sens. Actuators, B 2016, $228,43$.

12. Chelaghmia, M. L.; Nacef, M.; Affoune, A. M.; Pontié, M.; Derabla, T.; Electroanalysis 2018, 30, 1117.

13. Zhu, X.; Dou, X.; Dai, J.; An, X.; Guo, Y.; Zhang, L.; Tao, S.; Zhao, J.; Chu, W.; Zeng, X. C.; Wu, C.; Xie, Y.; Angew. Chem. 2016, 55, 12465. 
14. Yang, X.; Fu, K.; Mao, L.; Peng, W.; Jin, J.; Yang, S.; Li, G.; Chem. Eng. 2019, 205, 269.

15. Nunes, C. V.; Danczuk, M.; Bortoti, A. A.; Guimarães, R. R.; Gonçalves, J. M.; Araki, K.; Banczek, E. P.; Anaissi, F. J.; J. Electrochem. Soc. 2016, 163, A2356.

16. Nunes, C. V.; Danczuk, M.; Bortoti, A. A.; Gonçalves, J. M.; Araki, K.; Anaissi, F. J.; J. Power Sources 2015, 297, 408.

17. Miao, C.; Zhu, Y.; Huang, L.; Zhao, T.; J. Power Sources 2015, 274, 186.

18. Martins, P. R.; Toma, S. H.; Nakamura, M.; Toma, H. E.; Araki, $\mathrm{K} . ;$ RSC Adv. 2013, 3, 20261.

19. Sim, H.; Jo, C.; Yu, T.; Lim, E.; Yoon, S.; Lee, J. H.; Yoo, J.; Lee, J.; Lim, B.; Chem. Eur. 2014, 20, 14880.

20. Wu, X.-H.; Feng, Q.-P.; Wang, M.; Huang, G.-W.; J. Power Sources 2016, 329, 170.

21. Ehlsissen, K. T.; Delahaye-Vidal, A.; Genin, P.; Figlarz, M.; Willmann, P.; J. Mater. Chem. 1993, 3, 883.

22. Chen, H.; Hu, L.; Chen, M.; Yan, Y.; Wu, L.; Adv. Funct. Mater. 2014, 24, 934.

23. Li, M.; Jijie, R.; Barras, A.; Roussel, P.; Szunerits, S.; Boukherroub, R.; Electrochim. Acta 2019, 302, 1.

24. Li, Z.; Shao, M.; An, H.; Wang, Z.; Xu, S.; Wei, M.; Evans, D. G.; Duan, X.; Chem. Sci. 2015, 6, 6624.

25. Gonçalves, J. M.; Guimarães, R. R.; Brandão, B. B. N. S.; Saravia, L. P. H.; Rossini, P. O.; Nunes, C. V.; Bernardes, J. S.; Berttoti, M.; Angnes, L.; Araki, K.; Electrochim. Acta 2017, 247, 30.

26. Xie, W.; Song, Y.; Li, S.; Shao, M.; Wei, M.; Energy Environ. Mater. 2019, 2, 158

27. Indira, L.; Dixit, M.; Kamath, P. V.; J. Power Sources 1994, 52, 93.

28. Wang, D.; Pang, L.; Mou, H.; Zhou, Y.; Song, C.; RSC Adv. 2015, 5, 24101.

29. Feng, K.-J.; Yang, Y.-H.; Wang, Z.-J.; Jiang, J.-H.; Shen, G.-L.; Yu, R.-Q.; Talanta 2006, 70, 561.

30. Ispas, C.; Njagi, J.; Cates, M.; Andreescu, S.; J. Electrochem. Soc. 2008, 155, F169.

31. Xu, H.; Wang, B.; Shan, C.; Xi, P.; Liu, W.; Tang, Y.; ACS Appl. Mat. Interfaces 2018, 10, 6336.

32. Zhang, X.; Li, G.; Song, X.; Yang, S.; Sun, Z.; RSC Adv. 2017, 7,32442 .
33. Suárez-Quezada, M.; Romero-Ortiz, G.; Suárez, V.; MoralesMendoza, G.; Lartundo-Rojas, L.; Navarro-Cerón, E.; Tzompantzi, F.; Robles, S.; Gómez, R.; Mantilla, A.; Catal. Today 2016, 271, 213.

34. Rocha, M. A.; Anaissi, F. J.; Toma, H. E.; Araki, K.; Winnischofer, H.; Mater. Res. Bull. 2009, 44, 970.

35. Martins, P. R.; Rocha, M. A.; Angnes, L.; Toma, H. E.; Araki, K.; Electroanalysis 2011, 23, 2541.

36. Azeredo, N. F. B.; Rossini, P. O.; Gonçalves, J. M.; Assis, G. L.; Araki, K.; Angnes, L.; J. Taiwan Inst. Chem. Eng. 2019, 95, 475.

37. Xiang, Y.; Yu, X.-F.; He, D.-F.; Sun, Z.; Cao, Z.; Wang, Q.-Q.; Adv. Funct. Mater. 2011, 21, 4388.

38. Rocha, M. A.; Winnischofer, H.; Araki, K.; Anaissi, F. J.; Toma, H. E.; J. Nanosci. Nanotechnol. 2011, 11, 3985.

39. Hall, D. S.; Lockwood, D. J.; Bock, C.; MacDougall, B. R.; Proc. R. Soc. A 2015, 471.

40. Le Bihan, S.; Figlarz, M.; J. Cryst. Growth 1972, 13-14, 458.

41. Kowal, A.; Port, S. N.; Nichols, R. J.; Catal. Today 1997, 38, 483.

42. Rives, V.; Layered Double Hydroxides: Present and Future; Nova Science Publishers: New York, USA, 2001.

43. Choy, J.-H.; Kwon, Y.-M.; Han, K.-S.; Song, S.-W.; Chang, S. H.; Mater. Lett. 1998, 34, 356.

44. Canevari, T. C.; Cincotto, F. H.; Landers, R.; Machado, S. A. S.; Electrochim. Acta 2014, 147, 688.

45. Kim, M. S.; Kim, K. B.; J. Electrochem. Soc. 1998, 145, 507.

46. Danczuk, M.; Nunes, C. V.; Araki, K.; Anaissi, F. J.; J. Solid State Electrochem. 2014, 18, 2279.

47. Módolo, M. L.; Danczuk, M.; Anaissi, F. J.; Araki, K.; Fujiwara, S. T.; ECS Trans. 2014, 61, 319.

48. Shangguan, E.; Li, J.; Guo, D.; Guo, L.; Nie, M.; Chang, Z.; Yuan, X.-Z.; Wang, H.; J. Power Sources 2015, 282, 158.

49. Wang, X.; Lin, Y.; Su, Y.; Zhang, B.; Li, C.; Wang, H.; Wang, L.; Electrochim. Acta 2017, 225, 263.

50. Sivasakthi, P.; Sangaranarayanan, M. V.; New J. Chem. 2019, $43,8352$.

51. Simpson, D. E.; Juda, K. E.; Roy, D.; Electrocatalysis 2018, 9 , 86.

Submitted: December 8, 2019 Published oinline: June 30, 2020 